\title{
SPHINX JATROPH瓜.
}

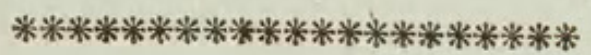

CHARACTER GENERICUS.

Ala subprismaticæ, utroque fine attennatæ.

Lingua exserta (plerisque).

Palpi duo reflexi.

Alce deflexæ.

Lin. Syst. Nat. Gmel. p. 2371.

CHARACTER SPECIFICUS, E`。

SPHINX grisea, alis superioribus nigro undulatis, corpore utrinque ocellis tribus luteis nigro marginatis.

SPHINX JATROPH死. S. alis subdentatis, posticis nigris basi rufis fasciaque fenestrata, capite bicorni.

$$
\text { Fab.Sp. Ins. 2. p. } 143 .
$$

In Surinamia innascitur Sphinx Jatrophæ, nec non in aliis Americæ Australis regionibus. Memoravit et depinxit hanc speciem celeberrima Domina Merian. Larva Jatrophæ gossypifoliæ ramulos præcipue depascitur. 



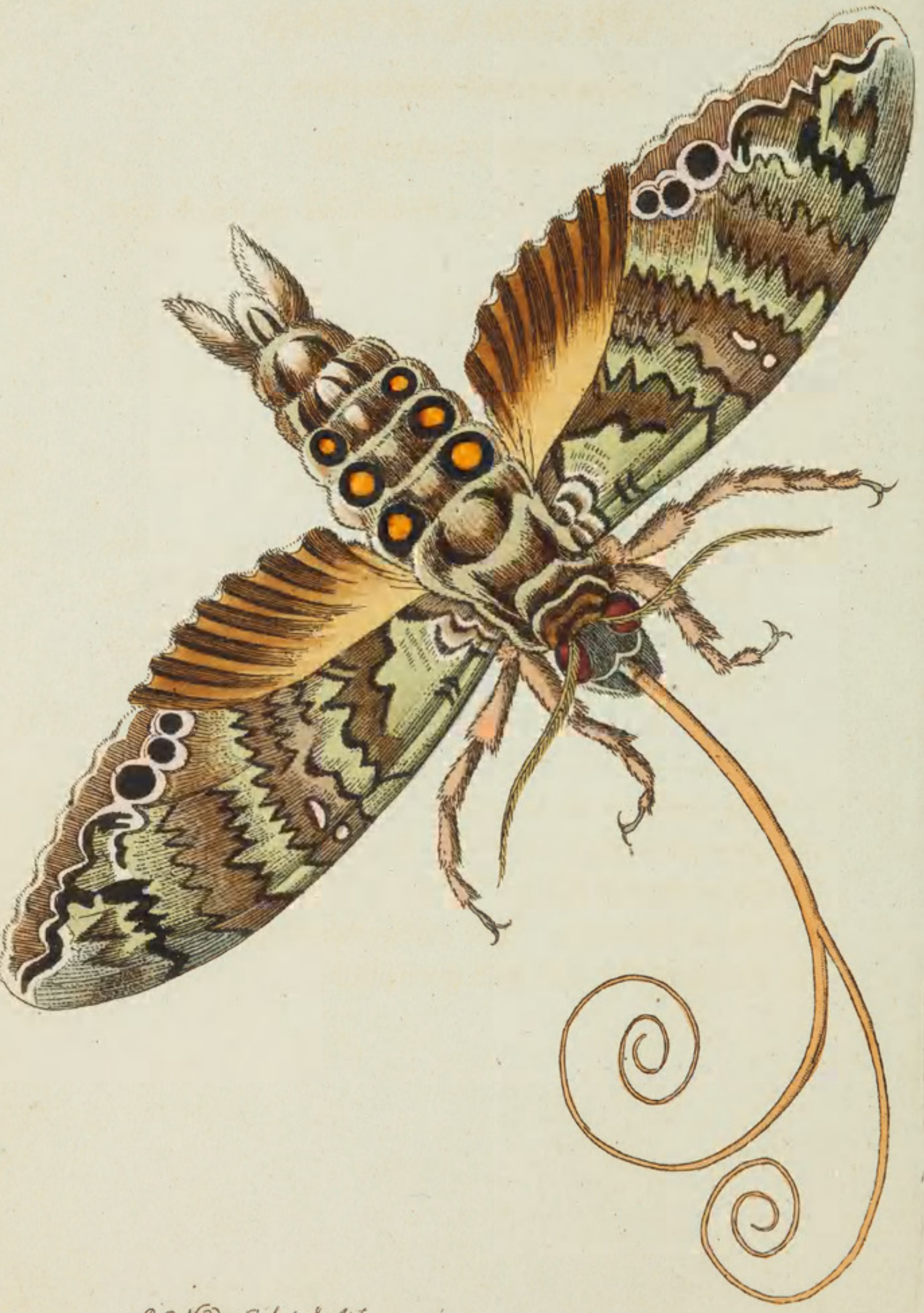

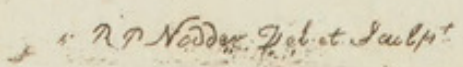




\section{JATROPHA SPHINX.}

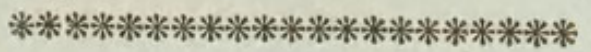

GENERIC CHARACTER.

Antennx subprismatic, attenuated at each extremity.

Tongue generally exserted.

Feelers two, reflex.

Wings deflected.

SPECIFIC CHARACTER, Eंc。

Grey SPHINX, with the upper wings undulated with black, and the body ocellated on each side by three yellow spots with black margins.

Merian Ins. Surin. pl. 38.

This insect is an inhabitant of Surinam, as well as of some other parts of South America, and is figured by the celebrated Madam Merian, in her work on the Insects of Surinam. The caterpillar feeds chiefly on the shoots of the Jatropha gossypifolia. 


\section{$2 \mathrm{BHL}$ Biodiversity Heritage Library}

Shaw, George. 1805. "The Jatrohpa Sphinx, Sphinx jatrophæ [PI. 679-680]." The Naturalist's Miscellany 16(CXCI), https://doi.org/10.5962/p.311118.

View This Item Online: https://www.biodiversitylibrary.org/item/281942

DOI: https://doi.org/10.5962/p.311118

Permalink: https://www.biodiversitylibrary.org/partpdf/311118

\section{Holding Institution}

Museums Victoria

\section{Sponsored by}

Atlas of Living Australia

\section{Copyright \& Reuse}

Copyright Status: Public domain. The BHL considers that this work is no longer under copyright protection.

This document was created from content at the Biodiversity Heritage Library, the world's largest open access digital library for biodiversity literature and archives. Visit BHL at https://www.biodiversitylibrary.org. 